\title{
Isolation and Characterization of Exopolysaccharide producing Bacillus cereus from Brown Seaweed- Sargassum wightii
}

\author{
V. A. Minimol*, Pankaj Kishore, Ranjit K. Nadella, K. R. Sreelakshmi, S. S. Greeshma, \\ M. M. Prasad and Suseela Mathew
}

ICAR-Central Institute of Fisheries Technology, Matsyapuri, P. O., Willingdon Island, Cochin, India

*Corresponding author

\section{Keywords \\ Exopolysaccharides, brown seaweeds, Bacillus cereus, FTIR \\ Article Info \\ Accepted: \\ 15 August 2019 \\ Available Online: \\ 10 September 2019}

\section{A B S T R A C T}

The bacterial extracellular polymeric substances (EPS) have huge applications in biotechnological and industrial sector. Biochemical composition determines its role in biofilm formation and pathogenicity as well as beneficial applications in various industries as thickeners, stabilizers, gelling agents etc. In the present study, aimed at screening the EPS producing bacteria from three species of brown seaweed and the EPS producing bacteria was isolated from Sargassium wightii. The EPS extraction was optimized and maximum production was recorded in BHI broth $\left(1.65 \mathrm{mg} \mathrm{ml}^{-1}\right)$ and media supplemented with glucose $\left(1.56 \mathrm{mg} \mathrm{ml}^{-1}\right)$. The extracted EPS contained $69.9 \%$ carbohydrate. Structural analysis by FTIR revealed the presence of carbohydrate (peak at $3292.93 \mathrm{~cm}^{-1}$, \& $1200-1000 \mathrm{~cm}^{-1}$ ) and S-S stretch (peak at $600 \mathrm{~cm}^{-1} \& 492 \mathrm{~cm}^{-1}$ ). The isolate was identified as Bacillus cereus by $16 \mathrm{~S}$ rRNA sequencing and species specific PCR targeting bla gene. Complete study on biochemical composition and structure of EPS will facilitate the employment of this novel biopolymer in food and pharmaceutical industry.

\section{Introduction}

Biopolymers are the polymers obtained from various biological organisms containing covalently bonded monomers and are classified into polysaccharides, polypeptides and polynucleotides (Ates, 2013). The main source of biopolymers from marine environment includes macro algae, micro algae, bacteria, and fungi. Among the microorganisms, bacteria are widely accepted as the source of exopolysaccharide with different functional properties and can be exploited for novel industrial and biotechnological applications. Exopolysacchrides (EPS) are high molecular weight polymers secreted by bacteria, consisting of different functional groups such 
as acetyl, succinyl or pyruvyl, sulfate etc (Tang et al., 2012). Traditional polysaccharide sources include both plant and algae which includes functional starch, glactomanan, pectin, carrageenan, pectin, and alginate (Vroman, and Tighzert, 2009). Microbial sources include xanthan gum, gellan, alginate, glucans, cellulose, hyaluronan, succinoglycan and levan (Zhao et al., 2017). Biodegradation ability of EPS from bacterial origin, can replace the traditional polysaccharides sources to a larger extent. However, the high cost of production and low yield from bacterial sources may limit the use in industrial scale.

Microbial cells generally contain extracellular biopolymeric structures which aids in rigidity as well as functional attributes to overcome adverse conditions. In general microbial cells produces two types of EPS, namely capsule EPS which produces during the log phase of bacterial growth and slime EPS which are produced mainly during the stationary phase (Plante and Shriver, 1998). The polysaccharide fraction of bacterial EPS mainly comprises of either homo polysaccharides or heteropolysaccharides (Kumar et al., 2007). The studies have been shown that the extracted extracellular materials (polysaccharides, lipids, glycoproteins and lipopolysaccharides) have wide applications in textile and food industries as stabilizers, gelling agents, adhesives, thickening agents, emulsifying agents, flocculants and flushing agents (Becker et al., 1998).

In the recent years, researchers are focusing on the bacterial communities and its interaction with seaweeds. Among all the microbes associated with seaweeds, bacteria can be seen either on seaweed surface or in cell cytosol and even determine the life cycle of eukaryotic organisms (Delbridge et al., 2004). Nicholas et al., (2005) reported better seaweed survival because of nutrient enhancement by bacterial EPS. In marine environment, EPS helps to increase the elemental uptake and dissolution of organic compounds which inturn make them available for microbial growth and other surrounding communities (Logan and Hunt, 1987). The bacterial associates with Laminaria japonica was reported to have plantlet growth promoting effect (Dimitrieva et al., 2006).

The exploitation of biopolymers with novel functionalities from marine environments has been considerably increased. In this study, an attempt was made to isolate and extract EPS produced from seaweed associated bacteria. Further, the chemical and structural properties of EPS produced from seaweed associated bacterium in pure cultures lead to unravel the constituents which will help to increase our understanding of the seaweed-bacterial association in the marine environment.

\section{Materials and Methods}

\section{Isolation and purification of bacteria producing exopolysaccharide (EPS)}

Three species of seaweed viz Sargassum wightii, Turbinaria connoides, Padina gymnocephalus were collected from Gulf of Mannar, Mandapam coast, Tamil Nadu (India) and screened for exopolysaccharide producing bacteria. A total of $25 \mathrm{~g}$ was dried seaweed aseptically suspended in phosphate buffered saline (1X) and serial dilutions were made. From each dilution, one $\mathrm{ml}$ was then inoculated into tubes of $9 \mathrm{ml}$ EPS culture medium containing $0.2 \mathrm{~g} \quad \mathrm{KH}_{2} \mathrm{PO}_{4} ; 1.5 \mathrm{~g}$ $\mathrm{K}_{2} \mathrm{HPO}_{4} ; \quad 0.2 \quad \mathrm{~g} \quad \mathrm{MgSO}_{4} .7 \mathrm{H}_{2} \mathrm{O} ; \quad 0.1 \mathrm{~g}$ $\mathrm{CaSO}_{4} \cdot 2 \mathrm{H}_{2} \mathrm{O} ; 2.0 \mathrm{mg} \mathrm{FeCl}_{3} ; 0.5 \mathrm{~g}$ yeast extract and $20 \mathrm{~g}$ sucrose (per liter). Then the samples were spread plated in duplicate onto trypticase soy agar (BD, Mumbai, India) and incubated at $37^{\circ} \mathrm{C}$ for $48 \mathrm{hrs}$. Bacteria that produce EPS characterized by colonies of bacteria that form thick slime (mucoid) was 
subsequently selected (Tallgren et al., 1999) and purified by streaking the four quadrants to obtain single colonies.

\section{Extraction of exopolysaccharide from} bacteria

EPS was extracted following the method of Berekaa and Ezzeldin (2018). The bacterial isolates were inoculated to the EPS culture medium and incubated at a temperature of $37^{\circ} \mathrm{C}$ for 10 days in the shaker incubator (MaxQ 6000,Thermoscientific,USA) with 200 $\mathrm{rpm}$ rotation. At the end of incubation, the cultures were centrifuged (Centrifuge 5804R, Eppendorf, India) at $9000 \mathrm{rpm}$ for $20 \mathrm{~min}$. The supernatant was collected and mixed with cold alcohol in 1:2 ratio. Deposition of biomass in the form of exopolysaccharide was washed with distilled water and dried at $60^{\circ} \mathrm{C}$ for 2-4 hours. The isolate which yielded maximum production of EPS was selected for further studies.

Effect of different culture media and carbon sources on Exopolysaccharide production

The liquid medium showing maximum yield was optimized by inoculating the bacterial culture in to three different liquid media i.e, luria bertani broth, trypticase soy broth, brain heart infusion broth supplemented with $2 \%$ glucose and incubated at a temperature of 37 ${ }^{\circ} \mathrm{C}$ for 10 days in shaker incubator at $200 \mathrm{rpm}$. Similarly, the effect of different carbon sources $(2 \%) v i z$. , glucose, maltose, fructose, cellobiose and trehalose on EPS production were also studied as per Sonawdekar and Gupte (2016).

\section{Biochemical characterization of crude EPS}

Chemical analysis of EPS was performed by determining the carbohydrate (Dubois et al., 1956), protein (Lowry et al., 1951), uronic
(Blumenkrantz, and Asboe-Hansen, 1973) and sulphate content (Cha et al., 1999).

\section{Structural characterization of crude EPS}

Structural analysis of crude EPS was carried out using FTIR (Fourier-transform infrared spectroscopy). Infrared spectra of the purified EPSs fractions were recorded in the 4000-400 $\mathrm{cm}^{-1}$ region using a FT-IR system (Nicolet iS 10, Thermo Fisher Scientific, USA)

\section{Biochemical and molecular identification of EPS producing bacteria}

Biochemical identification of the bacterial isolate was carried by tests such as Gram staining, oxidase, catalase, citrate utilization and starch hydrolysis (Tallent et al., 2012). The biochemically confirmed isolate was further confirmed by $16 \mathrm{~S}$ rRNA sequencing employing universal primers $27 \mathrm{~F}$ and $1492 \mathrm{R}$ (27F 5'-AGAGTTTGA TCCTGGCTCAG-3' and 1492R (5'-GGTTACCTTGTTACGAC TT-3') as well as Bacillus cereus specific PCR targeting bla gene (Das et al., 2009). Briefly, the crude DNA was extracted from the overnight culture by boiling method (Oliwa Stasiak et al., 2010). For 16S rRNA sequencing, amplification was performed using PCR mixture made to a final volume of $30 \mu \mathrm{l}$ containing $1 \mathrm{X}$ PCR buffer, $1.5 \mathrm{mM}$ $\mathrm{MgCl}_{2}, 2.5 \mu \mathrm{l}$ of each forward and reverse primer, $100 \mu \mathrm{M}$ of dNTPs mixed with $1 \mathrm{U}$ Taq DNA polymerase, $2 \mu \mathrm{l}$ of DNA template and rest by adding sterile Millipore water (Sanchez et al., 2011). The reaction was carried out in a thermocycler (Applied biosystem, USA) with following steps-an initial denaturation at $94^{\circ} \mathrm{C}$ for $2 \mathrm{~min}$, followed by 30 cycles of denaturation at $94^{\circ} \mathrm{C}$ for $30 \mathrm{sec}$, annealing at $52^{\circ} \mathrm{C}$ for $60 \mathrm{sec}$, extension at $68^{\circ} \mathrm{C}$ for $90 \mathrm{sec}$ and a final extension at $68^{\circ} \mathrm{C}$ for $7 \mathrm{~min}$. PCR reaction condition for the primer bla consisted of 30 cycles of $94^{\circ} \mathrm{C}$ for $45 \mathrm{sec}$ (denaturation), $55^{\circ} \mathrm{C}$ for $45 \mathrm{sec}$ (annealing) and $72^{\circ} \mathrm{C}$ for 45 
sec (extension). After amplification, the PCR products were analyzed by electrophoresis with $1.5 \%$ agarose gel. The partial bacterial 16S rRNA gene sequences were submitted to NCBI (National centre for biotechnology Information) BLAST search on the gene bank nucleotide database to identify the sequences with higher similarity.

\section{Results and Discussion}

\section{Screening of bacteria from seaweed for production of exopolysaccharides}

The exploitation of bacterial metabolites with bioactive potential from marine environment become a major area of research due to its biocompatible, non toxic properties which opt out the role of synthetic polymers to a large extent (Mano et al., 2007). Seaweeds are rich in bioactive polymers having commercial significance and major source of hydrocolloids such as alginate, agar and carrageenan. In the present study, brown seaweeds viz, Sargassum wightii, Padina gymnocephalus, and Turbinaria connoides were screened for EPS producing bacteria. Initial screening for EPS production by the bacterial isolates was carried out on the basis of appearance of colony on the TSA plate. A total of five distinct morphological isolates (B1, B2, C1, W1 and W2) from Sargassum wightii and Padina gymnocephalus were selected. A comparative study on the potential of these isolates for maximal production of exopolysaccharide was carried out by using liquid broth media. The colony characteristics of the selected isolates and EPS yield in EPS culture media are presented in Table 1. Out of five isolates, the isolate B1 from Sargassum wightii showed maximum EPS production $\left(1.06 \mathrm{mg} \mathrm{ml}^{-1}\right)$ and was selected for further studies (Fig 1). The EPS production is often accompanied with aging of the culture and exhaustion of available nutrients in the media. The appearance of thick slime/mucoid colonies on the solid media was taken to be the initial screening criteria for polysaccharide producing bacteria (Hereher et al., 2018). According to Mostefaoui et al., (2014) the probable easiest method for screening of EPS producing bacterial colonies is visual inspection even though it is insensitive.

The results of biochemical characterization of the isolates are depicted in Table 2. The isolate was identified as Bacillus cereus by $16 \mathrm{~S}$ rRNA sequencing and the sequences was submitted in the public domain with accession number MK595701.1. Polymerase chain reaction targeting species specific bla gene showed amplification of 533bp (Fig 2). Li et al., (2016) reported an extracellular matrix containing an unusual polysaccharide, in the dormant spores of B. cereus and investigated its key role in the adaptation and fitness to the environment. Sonawdekar and Gupte (2016) have isolated EPS producing $B$. cereus from oil contaminated sites from in and around Navi Mumbai and Thane districts of Maharashtra. Similarly, EPS producing Bacillus cereus GU 812900 was isolated from the stainless steel test panel and it contained $54 \%$ sugar and $1.85 \%$ protein (Bragadeeswaran et al., 2011). Singh and others (2011) identified the major bacteria associated with seaweeds Ulva and Gracilaria a Marinomonas spp. and Bacillus spp.

\section{Production of exopolysaccharides by Bacillus cereus}

\section{Effect of media}

The bacterial production of EPS depends highly on composition of substrate and environmental conditions (Rabha et al., 2012). Among different media tested for EPS production, the dry weight of EPS was recorded maximum in BHI $\left(1.65 \mathrm{mg} \mathrm{ml}^{-1}\right)$ followed by LB broth $\left(1.12 \mathrm{mg} \mathrm{ml}^{-1}\right)$ and TSB $\left(0.62 \mathrm{mg} \mathrm{ml}^{-1}\right)$, which indicate BHI medium 
provides suitable nutrients for the production of EPS. BHI is more nutritious than LB and TSB in terms of nitrogenous source and hence the bacteria get sufficient time to produce the polysaccharide to protect the deleterious effects of slow exhaustion of nutrients from the media. Pal and Paul (2013) reported that EPS production in Cupriavidus pauculus KPS 201 is positively influenced with the increase of nitrogen and phosphate in the growth medium.

\section{Effect of carbon source}

The effect of carbon source on EPS production by $B$. cereus was studied with both monosaccharides (glucose and fructose) and disaccharides (maltose, cellobiose and trehalose). Among the different sugars supplemented in media, glucose $\left(1.56 \mathrm{mg} \mathrm{ml}^{-}\right.$ 1) was most efficient for EPS production (Fig 3). It has been reported that the EPS production is directly correlated with the amount of carbohydrate present in the medium and its optimum concentration varies depending upon the individual microorganism (Ergene and Avc1, 2017). Glucose was the most efficient carbon source for Lactobacillus delbrueckii subsp. bulgaricus and Streptococcus thermophiles (Yuksekdag and Aslim, 2008). Grobben et al., (1997) reported that three times more production of EPS with glucose than fructose as sugar source and the type of EPS also varies with carbon source. These results are in contrary to Hereher et al., (2018) who reported that due to the relative ease of polymerization, disaccharides help in EPS production than monosaccharides. Further, Lee et al. (1997) observed that sucrose was efficient for the production of EPS from Bacillus polymyxa. The polysaccharide, starch was more effective in enhancing the EPS production by Pseudomonas stutzeri AS22 than glucose (Maalej et al., 2014).

\section{Chemical and structural analysis of EPS}

Fazio et al., (1982) have shown that EPS from marine bacterium is rich in galacturonic acids. During chemical analysis of the EPS from $B$. cereus, it was observed that EPS contained $69.9 \%$ carbohydrate, $8.1 \%$ protein, $3.2 \%$ total uronic content and $1.5 \%$ sulphate content.

This is in accordance with observation of Singh et al. (2011) who reported that the quantity of carbohydrates, protein and sulfate was 343.14, 107.68 and $50.28 \mathrm{mg} \mathrm{l}^{-1}$, respectively in EPS produced by Bacillus licheniformis.

Generally, the bacterial EPSs have higher carbohydrate content than sulphate and protein (Zhenming and Yan, 2005).

Structural analysis of EPS was carried out by FT-IR analysis (Fig. 4) which showed a characteristic N-H and $\mathrm{OH}$ stretch at around $3292.93 \mathrm{~cm}^{-1}$ and a $\mathrm{C}-\mathrm{H}$ stretching vibration at around $2925 \mathrm{~cm}^{-1}$ (Deepika et al., 2016).

The absorption peaks within $1650-1540 \mathrm{~cm}^{-1}$ attributed to vibrations of a $\mathrm{CO}, \mathrm{NH}$ and $\mathrm{CN}$ bending of protein and peptides.

The absorption peaks within $1200-1000 \mathrm{~cm}^{-1}$ attributed to vibrations of a broad stretch of $\mathrm{C}$ $\mathrm{O}$ and $\mathrm{C} \mathrm{O} \mathrm{C}$ glycosidic bands, which revealed the presence of carbohydrates (Zhang et al., 2013) that would be sugar monomers in the EPS.

The absorption peak at $600 \mathrm{~cm}^{-1}$ and $492 \mathrm{~cm}^{-1}$ could be attributed to the S-S stretch. The absorption observed at $1500-1600 \mathrm{~cm}^{-1}$ could be attributed to the stretching vibration of $\mathrm{C}=\mathrm{C}$ and $\mathrm{C}-\mathrm{N}$ groups. Peaks at $884 \mathrm{~cm}^{-1}$ ascertain the presence of glycosidic linkage bonds. The composition and components of exopolymeric substance of bacteria have large implications in their bioactive properties. 
Fig.1A) colony morphology of exopolysaccharide producing bacterial isolates on Trypticase soya agar and (B) crude extract of exopolysaccharide produced by Bacillus cereus in Luria bertani broth
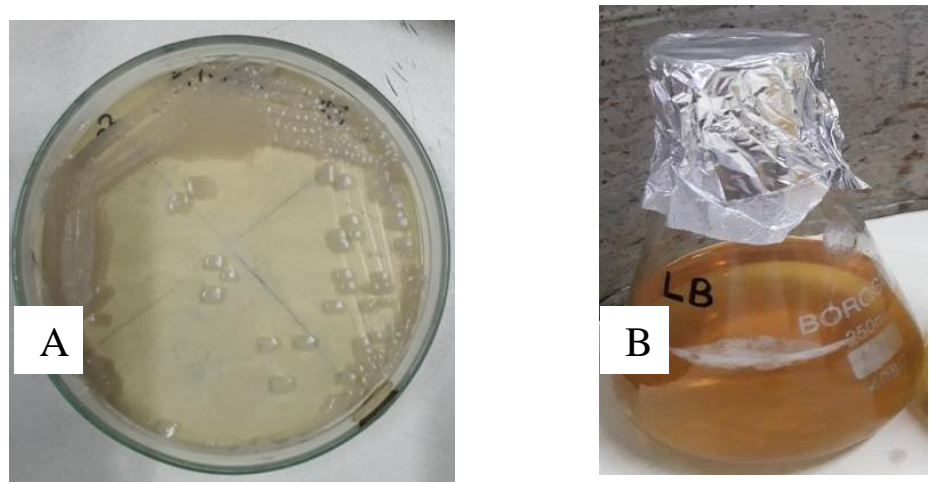

Fig.2 B cereus group specific PCR.

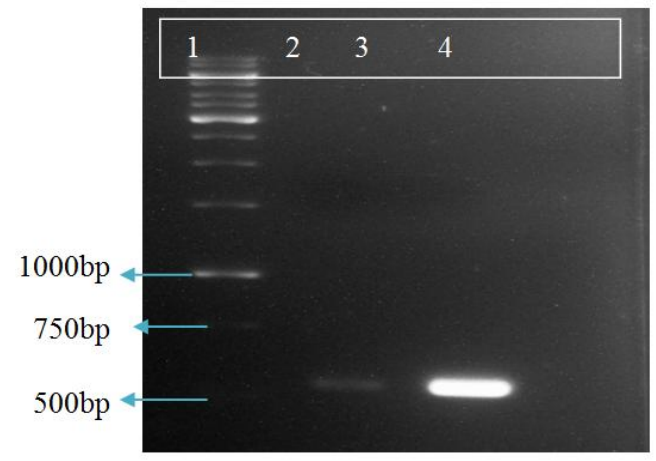

Lane 1: $1 \mathrm{~kb}$ ladder, Lane 2: B. cereus isolates recovered from S. wightii. Lane 3: Positive control, Lane 4: Negative control

Fig.3 Effect of different sugars on EPS production by Bacillus cereus

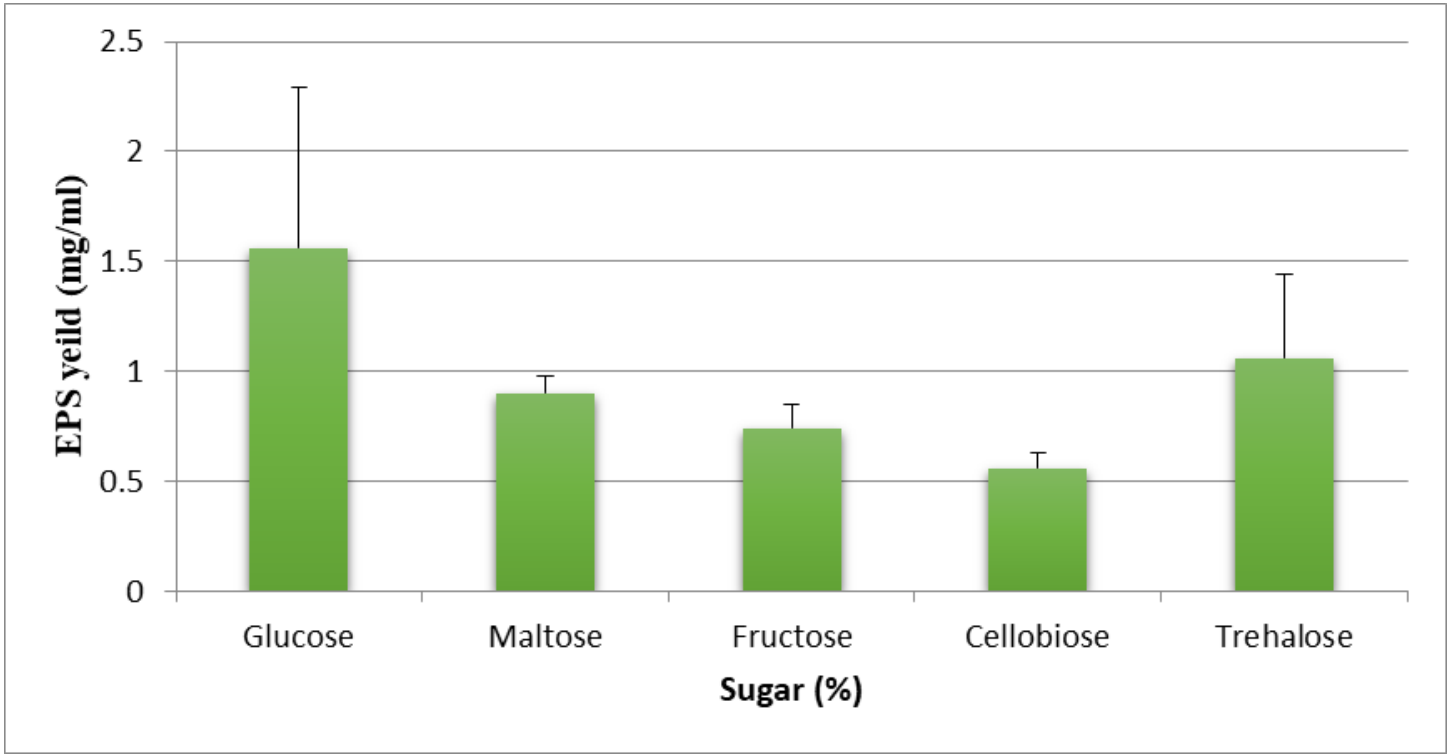


Table.1 Morphological and biochemical characteristics of the isolates and the EPS yield

\begin{tabular}{|c|c|c|c|c|c|}
\hline Isolates & BI & B2 & C1 & WI & W2 \\
\hline Sample source & $\begin{array}{l}\text { Sargassum } \\
\text { wightii }\end{array}$ & $\begin{array}{l}\text { Sargassum } \\
\text { wightii }\end{array}$ & $\begin{array}{l}\text { Sargassum } \\
\text { wightii }\end{array}$ & $\begin{array}{l}\text { Padina } \\
\text { gymnocephalus }\end{array}$ & $\begin{array}{l}\text { Padina } \\
\text { gymnocephalus }\end{array}$ \\
\hline Colony morphology & $\begin{array}{l}\text { Light } \\
\text { brown, } \\
\text { mucoid, } \\
\text { large 2-3mm } \\
\text { size, smooth }\end{array}$ & $\begin{array}{l}\text { Light } \\
\text { brown, } \\
\text { mucoid, } \\
\text { large 2-3mm } \\
\text { size, smooth }\end{array}$ & $\begin{array}{l}\text { Creamy, } \\
\text { mucoid, small } \\
1-2 \mathrm{~mm} \text { size, } \\
\text { smooth }\end{array}$ & $\begin{array}{l}\text { Whitish, Mucoid } \\
\text { large 2-3mm size, } \\
\text { irregular edge }\end{array}$ & $\begin{array}{l}\text { Whitish, Mucoid } \\
\text { large 2-3mm size, } \\
\text { irregular edge }\end{array}$ \\
\hline Gram reaction & $\begin{array}{l}\text { Gram } \\
\text { positive, } \\
\text { spore } \\
\text { forming, rod }\end{array}$ & $\begin{array}{l}\text { Gram } \\
\text { positive } \\
\text { spore } \\
\text { forming, rod }\end{array}$ & $\begin{array}{l}\text { Gram negative } \\
\text { non spore } \\
\text { forming, cocci }\end{array}$ & $\begin{array}{lr}\text { Gram } & \text { negative, } \\
\text { non } & \text { spore } \\
\text { forming, } \\
\text { shaped }\end{array}$ & Gram negative \\
\hline Oxidase reaction & Positive & Positive & Negative, & Positive & Positive \\
\hline Motilitiy & Motile & Motile & Non motile & Non motile & Non motile \\
\hline Indole & Negative & Negative & Negative & Positive & Positive \\
\hline Catalase & Positive & Positive & Positive & Positive & Positive \\
\hline Glucose fermentation & Positive & Positive & Positive & Positive & Positive \\
\hline Lactose fermentation & Negative & Negative & Positive & Negative & Negative \\
\hline Starch hydrolysis & Positive & Positive & Negative & Negative & Negative \\
\hline Protease activity & Positive & Positive & Negative & Negative & Negative \\
\hline Citrate utilization & Positive & Positive & Negative & Positive & Positive \\
\hline EPS yield $\left(\mathrm{mg} \mathrm{ml}^{-1}\right)$ & 0.82 & 1.06 & Nil & 0.3 & Nil \\
\hline
\end{tabular}

Fig.4 FT-IR Spectrum of crude EPS from Bacillus cereus

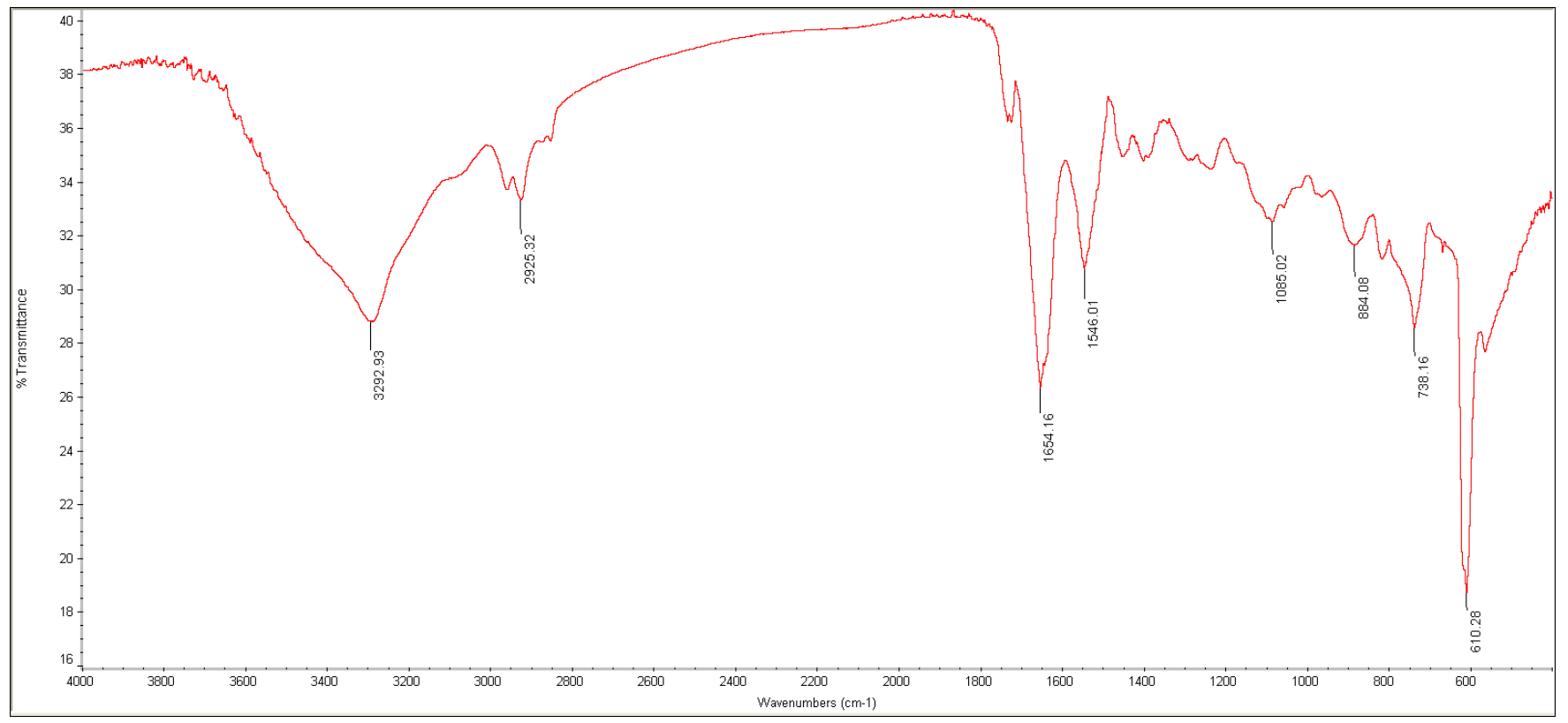


The present study gives an insight to the production of EPS by bacteria associated with Sargassum wightii, Turbinaria connoides, Padina gymnocephalus. Bacillus cereus was the potential EPS producing bacterium isolated and the EPS production was enhanced in the presence of glucose. The extracted exopolysaccharide from Bacillus cereus may be applied in many fields such as textiles, pharmaceuticals and food industry after carrying out further studies pertaining to its unique properties.

\section{References}

Ates, O., 2015. Systems biology of microbial exopolysaccharides production. Frontiers in bioengineering and biotechnology, 3, p.200.

Becker, A., Katzen, F., Pühler, A. and Ielpi, L., 1998. Xanthan gum biosynthesis and application: a biochemical/genetic perspective. Applied microbiology and biotechnology, 50(2), pp.145-152.

Berekaa, M.M. and Ezzeldin, M.F., 2018. Exopolysaccharide from Bacillus mojavensis DAS10-1; Production and Characterization. Journal of PurE and aPPliEd Microbiology, 12(2), pp.633640.

Berekaa, M.M. and Ezzeldin, M.F., 2018. Exopolysaccharide from Bacillus mojavensis DAS10-1; Production and Characterization. Journal of PurE and aPPliEd Microbiology, 12(2), pp.633640.

Blumenkrantz, N. and Asboe-Hansen, G., 1973. New method for quantitative determination of uronic acids. Analytical biochemistry, 54(2), pp.484-489.

Blumenkrantz, N. and Asboe-Hansen, G., 1973. New method for quantitative determination of uronic acids. Analytical biochemistry, 54(2), pp.484-489.

Bragadeeswaran, S., Jeevapriya, R., Prabhu, K., Rani, S.S., Priyadharsini, S. and
Balasubramanian, $\quad$ T., 2011.

Exopolysaccharide production by Bacillus cereus GU812900, a fouling marine bacterium. African Journal of Microbiology Research, 5(24), pp.41244132.

Cha, J.M., Cha, W.S. and Lee, J.H., 1999. Removal of organo-sulphur odour compounds by Thiobacillusnovellus SRM, sulphur-oxidizing microorganisms. Process Biochemistry, 34(6-7), pp.659-665.

Cha, J.M., Cha, W.S. and Lee, J.H., 1999. Removal of organo-sulphur odour compounds by Thiobacillusnovellus SRM, sulphur-oxidizing microorganisms. Process Biochemistry, 34(6-7), pp.659-665.

Dubois, M., Gilles, K.A., Hamilton, J.K., Rebers, P.T. and Smith, F., 1956. Colorimetric method for determination of sugars and related substances. Analytical chemistry, 28(3), pp.350-356.

Dubois, M., Gilles, K.A., Hamilton, J.K., Rebers, P.T. and Smith, F., 1956. Colorimetric method for determination of sugars and related substances. Analytical chemistry, 28(3), pp.350-356.

Ergene, E. and Avc1, A., 2017. Effects of Cultural Conditions on Exopolysaccharide Production by Bacillus sp. ZBP4. Journal of Agricultural Sciences, 24(3), pp.386393.

Kumar, A. S., Mody, K., and Jha, B. (2007). Bacterial exopolysaccharides-a perception. J. Basic Microbiol. 47(2), 103-117.

Li, Z., Hwang, S. and Bar-Peled, M., 2016. Discovery of a unique extracellular polysaccharide in members of the pathogenic Bacillus that can co-form with spores. Journal of Biological Chemistry, 291(36), pp.19051-19067.

Lowry, O.H., Rosebrough, N.J., Farr, A.L. and Randall, R.J., 1951. Protein 
measurement with the Folin phenol reagent. Journal of biological chemistry, 193, pp.265-275.

Lowry, O.H., Rosebrough, N.J., Farr, A.L. and Randall, R.J., 1951. Protein measurement with the Folin phenol reagent. Journal of biological chemistry, 193, pp.265-275.

Mano, J.F., Silva, G.A., Azevedo, H.S., Malafaya, P.B., Sousa, R.A., Silva, S.S., Boesel, L.F., Oliveira, J.M., Santos, T.C., Marques, A.P. and Neves, N.M., 2007. Natural origin biodegradable systems in tissue engineering and regenerative medicine: present status and some moving trends. Journal of the Royal Society Interface, 4(17), pp.9991030.

Oliwa-Stasiak, K., Molnar, C.I., Arshak, K., Bartoszcze, M. and Adley, C.C., 2010. Development of a PCR assay for identification of the Bacillus cereus group species. Journal of applied microbiology, 108(1), pp.266-273.

Pal, A. and Paul, A.K., 2013. Optimization of cultural conditions for production of extracellular polymeric substances (EPS) by serpentine rhizobacterium Cupriavidus pauculus KPS 201. Journal of Polymers, 2013.

Plante, C.J. and Shriver, A.G., 1998. Differential lysis of sedimentary bacteria by Arenicola marina L.: examination of cell wall structure and exopolymeric capsules as correlates. Journal of Experimental Marine Biology and Ecology, 229(1), pp.35-52.

Sanchez, M.C., Llama-Palacios, A., Blanc, V., Leon, R., Herrera, D. and Sanz, M., 2011. Structure, viability and bacterial kinetics of an in vitro biofilm model using six bacteria from the subgingival microbiota. Journal of periodontal research, 46(2), pp.252-260.

Sheetal Sonawdekar and Arpita Gupte. 2016. Production and Characterization of
Exopolysaccharide produced By Oil Emulsifying Bacteria. Int.J.Curr.Microbiol.App.Sci. 5(2): 254262.

Singh, R.P., Shukla, M.K., Mishra, A., Kumari, P., Reddy, C.R.K. and Jha, B., 2011. Isolation and characterization of exopolysaccharides from seaweed associated bacteria Bacillus licheniformis. Carbohydrate polymers, 84(3), pp.1019-1026.

Sonawdekar, S. and Gupte, A., 2016. Production and characterization of exopolysaccharide produced by oil emulsifying bacteria. Int $J$ Curr Microbiol App Sci, 5(2), pp.254-262.

Tallent, S.M., Kotewicz, K.M., Strain, E.A. and Bennett, R.W., 2012. Efficient isolation and identification of Bacillus cereus group. Journal of AOAC International, 95(2), pp.446-451.

Tallgren, A.H., Airaksinen, U., von Weissenberg, R., Ojamo, H., Kuusisto, J. and Leisola, M., 1999. Exopolysaccharide-producing bacteria from sugar beets. Appl. Environ. Microbiol., 65(2), pp.862-864.

Tang, X. Z., Kumar, P., Alavi, S., and Sandeep, K. P. (2012). Recent advances in biopolymers and biopolymer-based nanocomposites for food packaging materials. Crit. Rev. Food Sci. Nutr. 52, 426-442. doi:10.1080/10408398.2010.500508

Vroman, I., and Tighzert, L. (2009). Biodegradable polymers. Materials 2, 307-344. doi:10.3390/ma2020307

Zhang, N., Liu, X., Yu, L., Shanks, R., Petinaks, E. and Liu, H., 2013. Phase composition and interface of starchgelatin blends studied by synchrotron FTIR micro-spectroscopy. Carbohydrate polymers, 95(2), pp.649-653.

Zhang, N., Liu, X., Yu, L., Shanks, R., Petinaks, E. and Liu, H., 2013. Phase composition and interface of starch- 
gelatin blends studied by synchrotron FTIR micro-spectroscopy. Carbohydrate polymers, 95(2), pp.649-653.

Zhao, M., Cui, N., Qu, F., Huang, X., Yang, H., Nie, S., Zha, X., Cui, S.W., Nishinari, K., Phillips, G.O. and Fang,
Y., 2017. Novel nano-particulated exopolysaccharide produced by Klebsiella sp. PHRC1. 001. Carbohydrate polymers, 171, pp.252258.

\section{How to cite this article:}

Minimol, V. A., Pankaj Kishore, Ranjit K. Nadella, K. R. Sreelakshmi, S. S. Greeshma, M. M. Prasad and Suseela Mathew 2019. Isolation and Characterization of Exopolysaccharide producing Bacillus cereus from Brown Seaweed-Sargassum wightii. Int.J.Curr.Microbiol.App.Sci. 8(09): 1302-1311. doi: https://doi.org/10.20546/ijcmas.2019.809.149 